\begin{tabular}{|l|c|c|c|c|}
\hline $\begin{array}{l}\text { Cuadernos de Investigación Geográfica } \\
\text { Geographical Research Letters }\end{array}$ & 2020 & N $^{\circ} 46(2)$ & pp. 545-561 & eISSN 1697-9540 \\
\hline
\end{tabular}

DOI: http://doi.org/10.18172/cig.4290

(C) Universidad de La Rioja

\title{
NEW DOCUMENTARY DATA ON THE CLIMATE IN SOUTHERN SPAIN FROM 1792 TO 1808
}

\author{
F.S. RODRIGO* \\ Departamento de Química y Física, Universidad de Almería, Ctra. Sacramento. \\ La Cañada de San Urbano s/n, 04120 Almería, Spain.
}

\begin{abstract}
This work presents a new source of documentary data on the Spanish climate from 1792 to 1808 coming from the periodical Correo Mercantil de España y sus Indias, in which weekly summaries of Spanish weather conditions were published. The potential of this data source for historical climatology studies is analysed, focusing on information related to the south of the Iberian Peninsula.
\end{abstract}

Nuevos datos documentales sobre el clima del sur de España desde 1792 a 1808

RESUMEN. En este trabajo se presenta una nueva fuente de datos documentales sobre el clima de España de 1792 a 1808. Se trata del periódico Correo Mercantil de España y sus Indias, donde se publicaban resúmenes de las condiciones meteorológicas en España a resolución semanal. Se analiza el potencial de esta fuente de datos para los estudios de climatología histórica, centrando el estudio en las informaciones relativas al sur de la Península Ibérica.

Key words: Historical climatology, southern Spain, Dalton Minimum, extreme events.

Palabras clave: Climatología histórica, sur de España, Mínimo de Dalton, eventos extremos.

Received: 12 June 2019

Accepted: 14 January 2020

*Corresponding author: F.S. Rodrigo, Departamento de Química y Física, Universidad de Almería, Ctra. Sacramento, La Cañada de San Urbano s/n, 04120 Almería. E-mail address: frodrigo@ual.es

\section{Introduction}

Analysis of historical documents is a useful method for reconstructing the climatic conditions of the pre-instrumental period, i.e. the period before the beginning of systematic 
weather observations which began around the mid-19 $9^{\text {th }}$ century (Jones et al., 2009; Brázdil et al., 2010). In Spain, many works have used historical documents to reconstruct the past climate (see, for example, Domínguez-Castro et al., 2010). The volume of historical documents that are potentially useful for historical climatology increased significantly during the eighteenth century and the early decades of the nineteenth century. Over this period there were different initiatives aimed at compiling useful weather observations for sailing, medicine and agriculture (Anduaga Egaña, 2012). Many of them were published in books, reports and periodicals (Barriendos et al., 2002). The first weather data for Spain, however, are part of a heterogeneous, fragmentary and dispersed data set, with incomplete information regarding the observational methods, and for which only a few cities (Cadiz, Madrid, Barcelona) possess long and continuous series of meteorological data (Domínguez-Castro et al., 2014). Therefore, it is still necessary to complete this data set with new documentary sources that report on the climatic conditions during the last decades of the eighteenth century and the beginning of the nineteenth century. This period is particularly interesting because it corresponds to the central phase of the so-called Dalton Minimum of solar activity 1790-1830 (Usokin, 2017), when intense volcanic activity was also detected (Pisek and Brázdil, 2006). It therefore relates to a historical moment prior to current global warming, and in which natural radiative factors might have affected the global climate (Wagner and Zorita, 2005).

The Iberian Peninsula (IP) has been considered an area especially sensitive to climate change (Giorgi, 2006) due to its geographical and latitudinal position at the western end of the Mediterranean Basin. Its climatic conditions are governed by flows of both Atlantic and Mediterranean origin, modulated by a varied topography, with abrupt altitude gradients in a relatively small area (Martín-Vide and Olcina-Cantos, 2001). Consequently, the study of IP climate during a period, such as the Dalton Minimum, could be particularly interesting.

The main objective of this work is to present a new source of documentary data with climate information on Spain during this period. This source is the periodical Correo Mercantil de España y sus Indias (The Mercantile Mail of Spain and the Spanish Indies), henceforth denoted as CMEI, which was published from 1792 to 1808. In this work, we focus on the news regarding the south of Spain, leaving the analysis of other geographical areas for future works. Section 2 describes the data source while the meteorological information and spatial data coverage is explained in Section 3 along with the potential use of this information; a brief discussion is included in Section 4 and finally, in the last section, we present some findings and prospective research for the future.

\section{The periodical Correo Mercantil de España y sus Indias}

The importance of meteorological events was a common concern in the pre-industrial era, when the main economic activities were agriculture and livestock. In countries with a strong Catholic tradition such as Spain, a common practice was the organization of religious processions asking for rain (pro-pluvia rogations) or stable rainfall conditions (pro-serenitate rogations) (Barriendos, 1997). During the Enlightenment in the $18^{\text {th }}$ century, religious practices were progressively accompanied by 'scientific' initiatives in 
which crop responses to different climatic conditions began to be studied. An example of this was the periodical Semanario de Agricultura y Artes dirigido a los Párrocos (The Agriculture and Arts Weekly addressed to the Parish Priests; 1797-1808), where the reader could find articles relating to the weather and agricultural production. This interest can also be found in private initiatives, such as correspondence from the major-domo of the county of Zafra (Extremadura) to the landowner from the mid-18 ${ }^{\text {th }}$ to the mid-19 century (Fernández-Fernández et al., 2014). In this context, the CMEI periodical began publication on $1^{\text {st }}$ October 1792, edited by Diego María Gallard (¿?-1824) and Eugenio Larruga (1747-1883). Copies of this periodical have been digitized and are available on the National Library of Spain website (http://hemerotecadigital.bne). There are two large gaps from July to November 1798, and from July 1804 to July 1806 . We have not been able to find the missing copies. However, the analysis of this data source can be an interesting contribution to historical Spanish climatology.

The editors were Spanish government officials dedicated to fiscal and financial policy. Initially the periodical was the private initiative of the editors, but from 1800 it was funded by the Spanish government. It included news, articles and reports on trade, advances and inventions, statistical data, economics, port activity, government regulations and foreign exchange, etc. The editors established a network of correspondents, mainly the so-called Sociedades de amigos del pais (Societies of friends of the country), local economic groupings which, following Enlightenment principles, tried to extend new ideas in each city. As an example, the Community Archive of Valencia (UPV, 1793) has conserved a letter signed by Larruga and Gallard, in which they write to the Valencian economic society saying that "le suplicamos a V.S. se sirva comunicarnos todas aquellas noticias que puedan convenir al público en los particulares que abraza nuestro Periódico" (we would ask V.S. that they communicate to us all the news that may be of interest to the public regarding the particulars covered by our periodical). These requests were answered from the different provinces (copies of the responses of the Santander Society can be found in the Public Archive of Cantabria (CAN, 1792-1809)). The periodical was published until $30^{\text {th }}$ June 1808 , when the Napoleonic invasion interrupted its production. It is considered an important historical source on economic and political conditions in Spain during those years (García Fernández, 1959; Anés Álvarez, 1981), but its usefulness in terms of historical climatology has not yet been studied.

The periodical appeared twice a week, on Mondays and Thursdays, alternating information from the northern and southern provinces each day, thus providing a weekly summary of the general conditions (economic, agricultural, meteorological) across the country. All the editions began with a report on agriculture, qualitatively describing general weather conditions and indicating the grain prices (Fig. 1). The meteorological information was classified by province, taking into account the territorial division of Spain during those years. In October 1799, new provinces (Oviedo, Santander, Cádiz, Malaga, Cartagena and Alicante) were established to recognise the importance of the seaports (Gómez-Mendoza and García Álvarez, 2001). This fact was considered by the publishers although it did not alter the basic outline of the reports. Figure 2 shows the location of major cities in southern Spain for which there is information. 


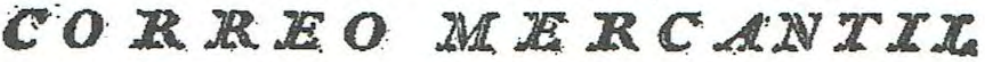 DE ESPANA Y SUS INDIAS}

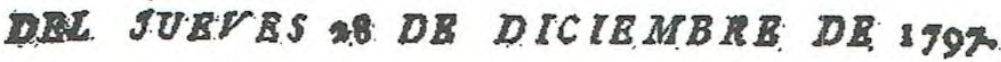

\section{AGRICULTURA.}

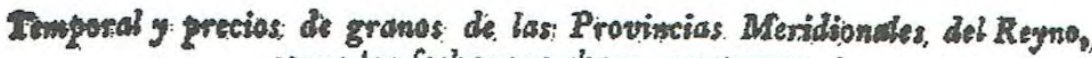
segwr las fechos que obasso se exprescon.

$\boldsymbol{E}$ Fin: las Provincias de Madrid, Tolsdo, Mancha, Murcia. y Granada ba quedado el tiempo muy frio. y claro: en. las de Guenca y Jaén está Llovioso: en la de. Exremadura se experimentan, nieblas fries; y últiaramente en las de Córdova, Valencia y Sevalla permaliece sereno 8 regular. Los precios, corrientes de los granos en: estas provincias han rido, la Eanega de trigo de 45 a 1110 reales, y la, de sebada de 23 ác 63 . reda. en la forma, que sigue.

Provincias y Partidos.

Fechas. Trige. Cebadto.

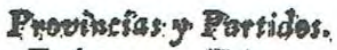

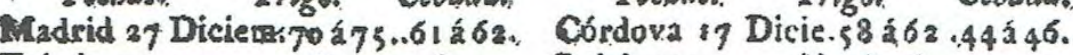

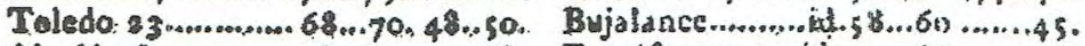

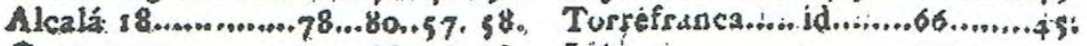

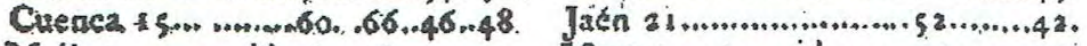

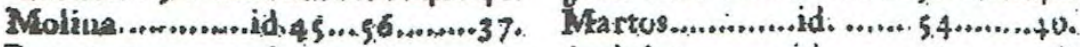

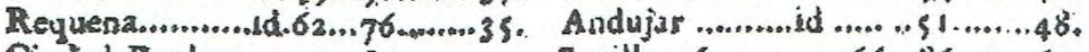

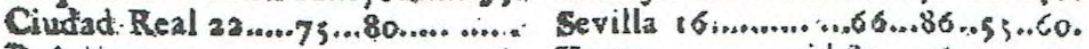

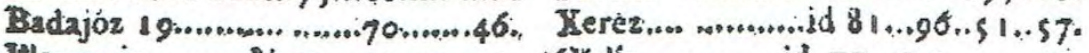

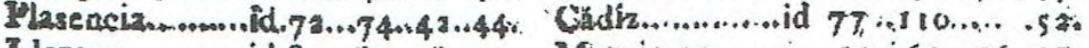

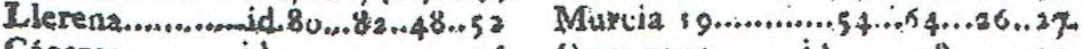

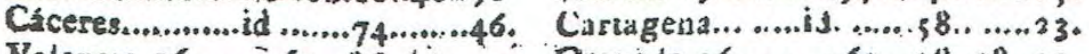

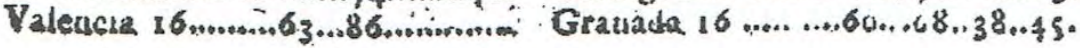

Comparados estos pereios con lós de la semana anterior, se nota la diferencia de traber subide el trigo en Mur la a reales, y eu Cispduva

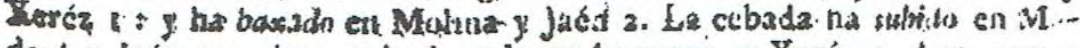

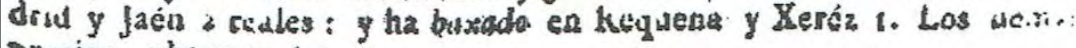

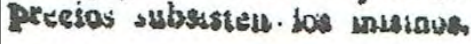

Figure 1. Front page of the issue 104 (28/12/1797) of CMEI (http://hemerotecadigital.bne.es). 


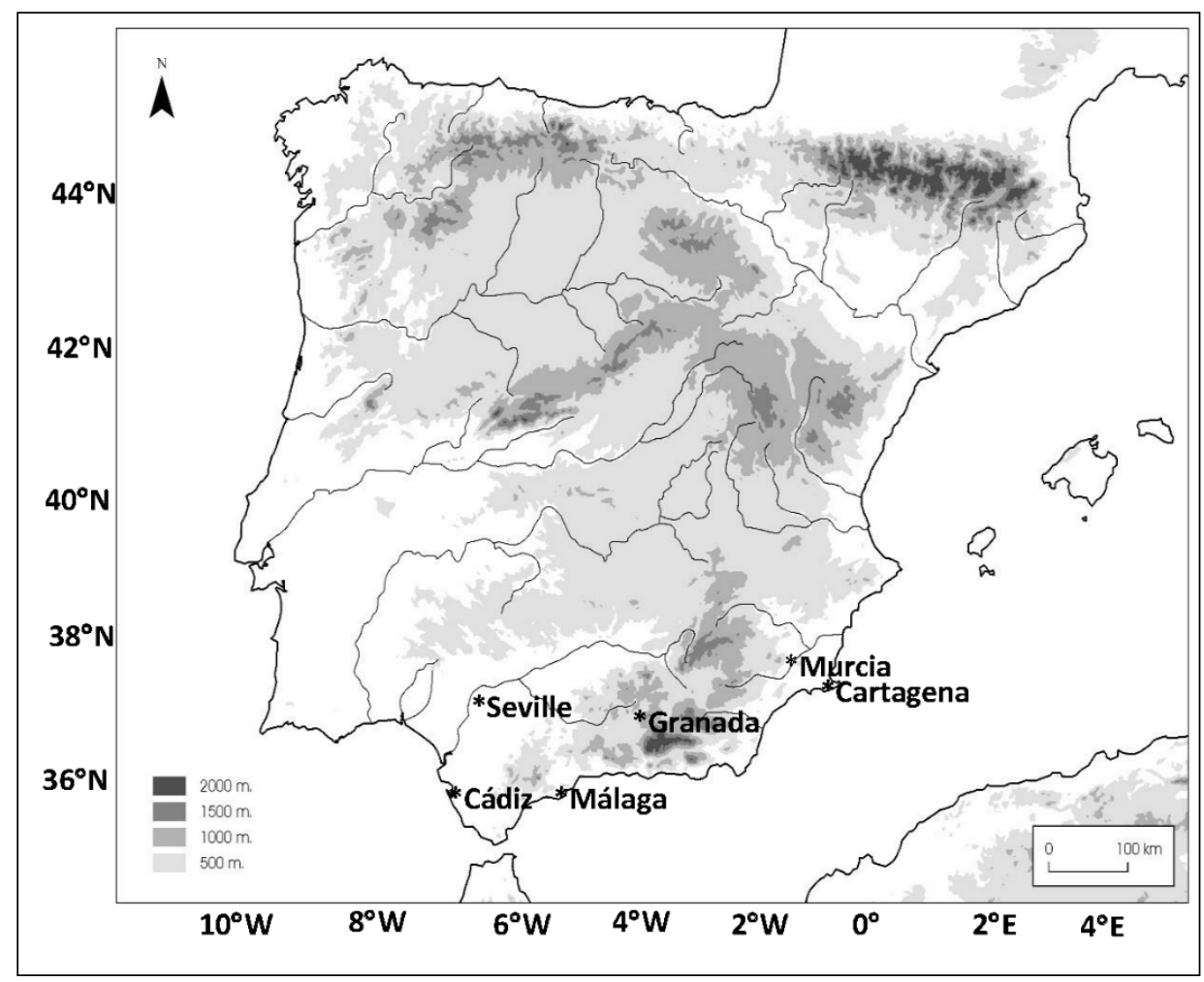

Figure 2. Main cities in southern Spain with climatic information in CMEI, 1792-1808.

The reports are a summary of the general weather conditions, where the editors transmit the information corresponding to different locations within each province. The number of cities mentioned within each province varies depending on the date of the reports. Therefore, the information this source provides is mainly a spatial average of the meteorological events, according to the territorial division of the period, although sometimes differences are specified between several localities within the same province.

The information found in the first issues (until April 1793) is presented simultaneously for all the provinces, indicating the dates the information refers to in the section subtitle. Sometimes, information is not provided for all the provinces, probably due to lack of responses from local correspondents, problems with the mail and transportation, lost information or editorial errors. After a few months (from issue 5, page 29 of Monday, $15^{\text {th }}$ April 1793), the information ceased being simultaneous between the different provinces and instead the date of the information for each province was indicated in the list of grain prices (Fig. 1). 


\section{Weather information and its potential use}

\subsection{Descriptors of weather phenomena}

The periodical's weekly determination of the meteorological information provides a first point of interest for the analysis of this data source - the descriptions report not only extreme events, but also the 'normal' conditions for the period of study. Thus, it is common for comments such as "propio de la estación" (seasonal weather) or "según la estación" (depending on the season) to appear.

Weather reports are directly related to the different phases of plant growth, showing special interest in weather conditions during the autumn cereal planting and harvesting at the beginning of summer. However, it was not only cereals that focused the correspondents' attention, they also reported on other crops (fruits, olives, maize, livestock pastures etc.). For example, the report for the week of the $14^{\text {th }}$ to $21^{\text {st }}$ November 1792 in Sevilla (issue 17, page 133, 1792) states that "el tiempo es benigno, claro y despejado, favorable a la sementera y recolección de bellota y aceytuna" (the weather is kind, clear and cloudless, favourable for the sowing and harvesting of acorns and olives). Different crops have different climatic requirements (for example, barley is more resistant to spring drought than wheat), and, for any given crop, depends on the phenological phase of plant growth. Sometimes, correspondents specify the conditions and crops they are interested in, but at other times, they make only vague comments with statements such as "favourable para los frutos" (favourable to fruits), "apropiado para las plantas" (appropriate for the plants), etc. In these cases, it is difficult to establish what the predominant weather conditions were.

Many of the comments are direct descriptions of weather events, focusing attention on the thermal and rainfall regime, although other phenomena, such as fog, wind (sometimes indicating predominant directions), storms, and cloudiness are also registered.

In relation to temperature, the source distinguishes between warm, temperate and cold conditions. Warm conditions are often described using expressions such as "fuerte calor" (strong heat),"calor vehemente" (vehement heat), or "calor excesivo" (excessive heat). Information on cold conditions is accompanied by similar qualifiers, along with the occurrence of "hielo" (ice), "heladas" (frost) or "nieve" (snow). Temperate weather is identified by terms such as "templado" (mild), "suave" (soft)" or "bueno" (good). This information can be classified using an index (it) for each piece of information with the values it=+1 (warm), 0 (normal), -1 (cold).

In the case of rain, it is possible to distinguish between light rain ("llovió un poco" (it rained a little), "llovió algo" (it rained some), "llovió por algunas partes" (rained in some parts)), moderate rain ("llovió" (it rained), "llovió bien" (it rained well)), and heavy rains ("llovió copiosamente" (it rained copiously), "llovió en abundancia" (abundant rain)). On the other hand, comments about "cielos claros" (clear skies), "despejados" (cloudless), "soleados" (sunny) or "atmósfera serena" (serene atmosphere) allow us to distinguish those weeks when there was an absence of rain. This information makes it 
possible to establish a gradation, and assign an index value, ir $=0,1,2,3$, according to whether the reports refer to the absence of rains, light and/or patchy rains, moderate rains or heavy rains, respectively.

Other descriptors are more general and vaguer, such as "húmedo" (humid), "revuelto" (changeable), "vario" (varied), and "regular" (as opposed to varied). The "humid" descriptor may correspond to assessments of atmospheric humidity, the appearance of dew, frost, fog or rain. The terms "changeable" and "varied" are sometimes related to changes in the predominant wind direction, conditions alternating from cloudless to cloudy, scattered rain showers, cold/warm and mild temperatures, or a combination of some of these situations. Only by comparing with other independent data sources can the true meaning of these concepts be clarified.

\subsection{Information at the national level}

A feature of this data source is that it allows one to perceive the spatial coverage of different events on the Iberian Peninsula. As an example, Figure 3 shows the conditions for the week of January $16^{\text {th }}$ to $23^{\text {rd }}, 1793$ (issues 8 and 9 , pages 57 and 65,1793 ). Issue 8 (published on 28/01/1793) reports on the southern provinces indicating that:

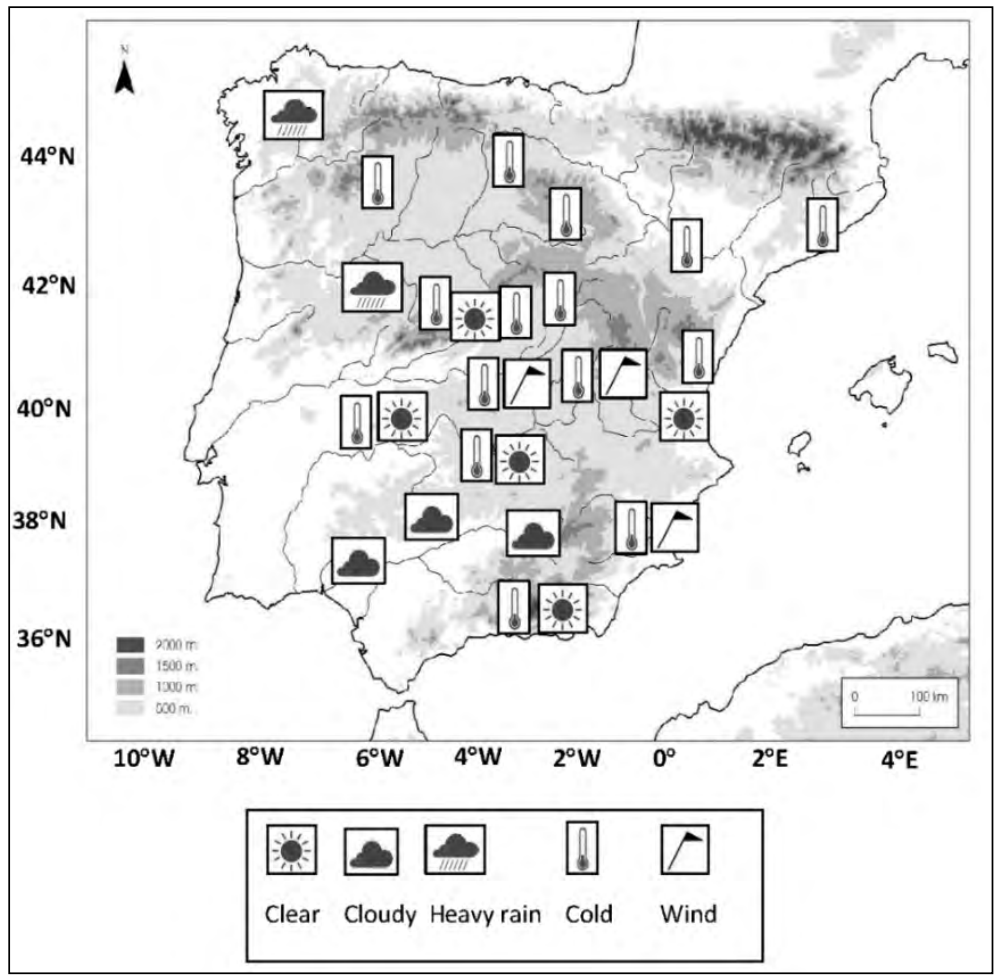

Figure 3. Weather conditions in Spain from 16 to 23 January 1793, according to CMEI. 
"En las Provincias de Madrid, Mancha, Extremadura, Granada y Valencia se ha experimentado un tiempo frío y seco, lo que ha sido prejudicial a los campos. En las de Toledo, Murcia y Cuenca han hecho vientos frios, y escarchas con alguna humedad; y en las de Jaén, Cordova, y Sevilla se ha sentido un tiempo propio de la estacion, con aparatos de lluvia" (In the provinces of Madrid, Mancha, Extremadura, Granada and Valencia, there has been cold, dry weather, which has been prejudicial in the fields. In (the provinces) of Toledo, Murcia and Cuenca, there have been cold winds and frosts with some humidity; while in (the provinces) of Jaén, Córdoba, and Sevilla, seasonal weather has been felt with apparatus of rain).

Issue $9(31 / 01 / 1793)$ focuses on the septentrional (northern) provinces:

"En las Provincias de Avila, Aragón, Burgos, Cataluña, Zamora, Guadalaxara, y Soria, se ha experimentado un tiempo sumamente frio, con hielos y escarchas, y tambien alguna humedad; y en las de Valladolid, Toro, Segovia, Palencia, Leon, Galicia, y Salamanca, ha hecho un tiempo regular y favorable para los campos, especialmente en estas dos ultimas que ha llovido bastante". (In the provinces of Avila, Aragon, Burgos, Catalonia, Zamora, Guadalaxara, and Soria, there has been extremely cold weather, with ice and frost, and also some humidity; and in those of Valladolid, Toro, Segovia, Palencia, Leon, Galicia, and Salamanca, there has been regular and favourable weather for the fields, especially in the last two, where it has rained quite a lot).

These reports can be represented on a map to obtain an overview of the weather for that week. As can be seen in Figure 3, cold conditions prevailed across the country. Heavy rains are reported to the north west, skies covered to the south west, and sunny weather with winds (no wind direction specified) in the centre and south east of the country. This situation seems to reflect the advection of humid air masses from the Atlantic, with cyclonic activity invading the Iberian Peninsula from the north-west, a very common situation in winter on the peninsula (Martín Vide and Olcina Cantos, 2001).

\subsection{Information about the provinces}

Figure 4 shows the annual number of reports from the southern provinces (Sevilla, Córdoba, Jaén, Granada and Murcia) from 1792 to 1808. If we consider that the optimal number of weekly reports is $\geq 3$ reports/month (Fernández-Fernández et al., 2015), then the optimal number of annual reports would be $\geq 36$. The lowest number of reports obviously corresponds to 1792 (since the periodical only began to be published in October) and to 1808 (when the periodical ceased in June). There are also evident gaps due to the loss of specimens (1798, and from mid-1804 to mid1806). Therefore, the years that have sufficient information are 1793-1797, 17991803 , and 1807. However, there are differences between provinces; for example, the number of reports for Sevilla from 1800 to 1803 is clearly insufficient (less than 30 annual reports). This should be taken into account when studying each individual province. 


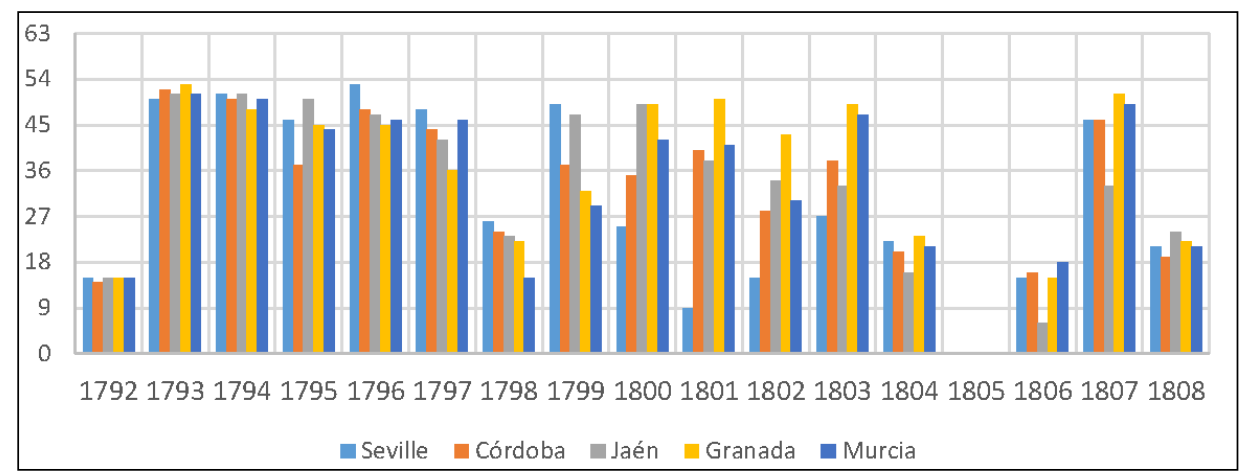

Figure 4. Annual number of records in southern provinces (Seville, Córdoba, Jaén, Granada, and Murcia) from 1792 to 1808.

The climate in Spain experiences clear seasonality, with marked differences between winter (December to February) and summer (June to August), while spring (March to May) and autumn (September to November) are transitional seasons. Therefore, the study was carried out separately for each season of the year. For each year, we counted the number of weekly records. The optimal number of seasonal records was set at $\geq 9$, considering that 3 or more weekly records/month were sufficient (Fernández-Fernández et al., 2015).

Figure 5 shows the data treatment followed, using the spring data for Córdoba as an example. Considering our criterion for the optimal number of seasonal records, we removed the years 1795, 1802, 1803, 1805, and 1806 from the analysis (Fig. 5a). The main impacts of the weather on wheat come from precipitation, especially during planting in autumn and in spring prior to harvest. This explains the prevalence of rainrelated information rather than other weather variables. However, the authors were aware of the climatic requirements for the plants from sowing to harvest (e.g. moderately cold conditions in winter are important for the rooting of wheat), so they considered not only the rainfall regimen, but also other meteorological events, in particular, the thermal conditions. The next step was to count (for the years with a sufficient number of records) the percentage of records related to cold or warm weather (it $=-1,+1$, respectively), and the presence or absence of rain (ir $>0$, ir $=0$, respectively) (Fig. 5b, 5c). Ambiguous terms were not considered at this stage of the analysis. Note that the classification indicates the average weather conditions for each season and province, not the extremes possible for a particular season.

Our hypothesis here is that the general character (cold/warm and/or wet/dry) of the weather for each season is indicated by the highest percentage. For example, the percentage of records describing precipitation (absence of rain) in Córdoba during the spring of 1796 was $61.5 \%$ (30.8\%), thus allowing us to classify this season as wet. 


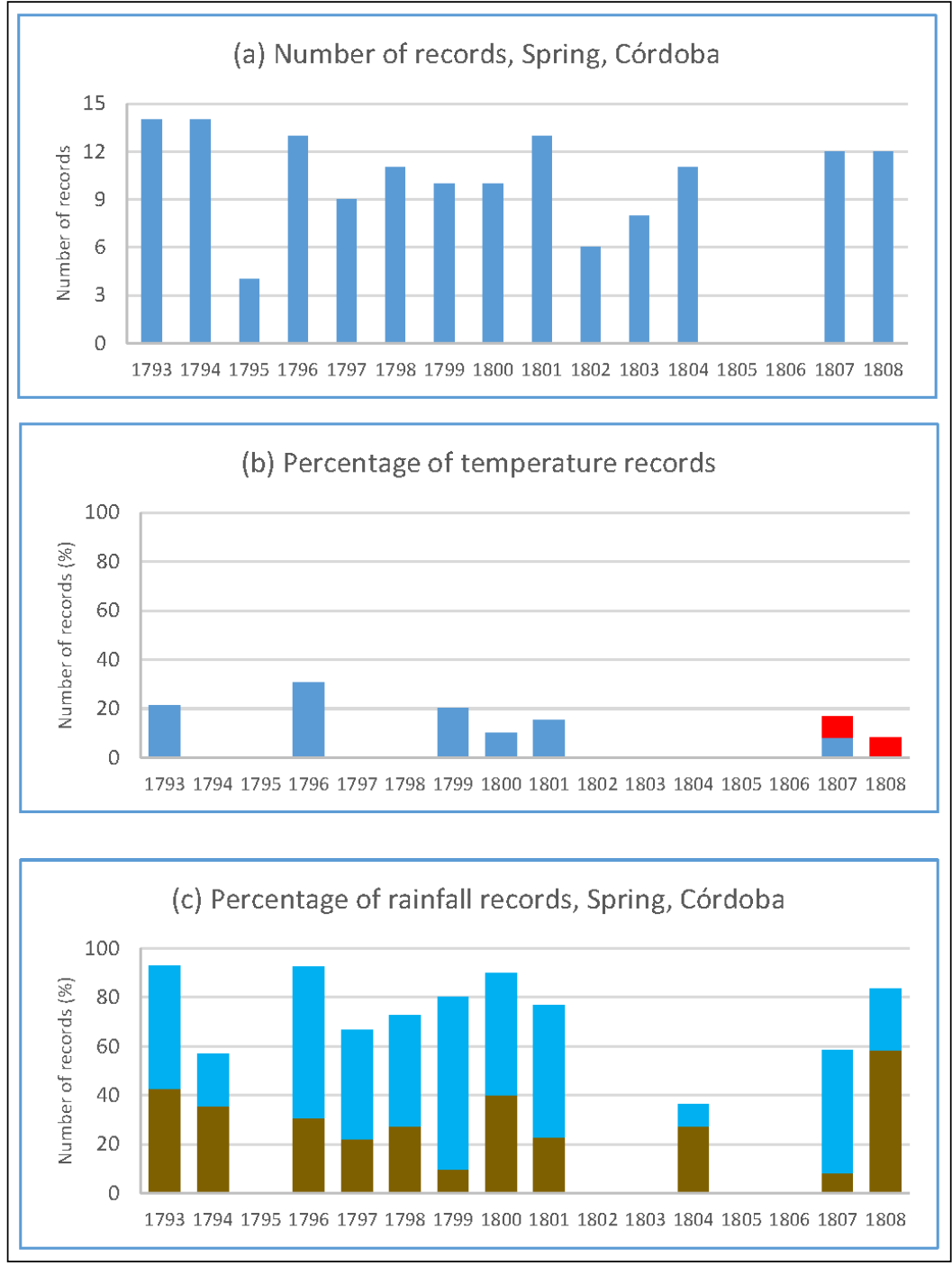

Figure 5. (a) Number of spring records in Córdoba from 1792 to 1808. (b) Percentage of records indicating cold (blue) and warm (red) conditions. (c) Percentage of records indicating dry (brown) and rainy (blue) conditions.

Figure 6 shows the results for spring in the five provinces studied. Although there are slight local differences, you can see that cold conditions predominate. With regard to rainfall, wet conditions predominated in the early years of this period, while dry conditions increased, more frequently in the eastern provinces (Granada and Murcia). A more detailed analysis of the results over the four seasons of the year is the subject of a study presently being prepared. 


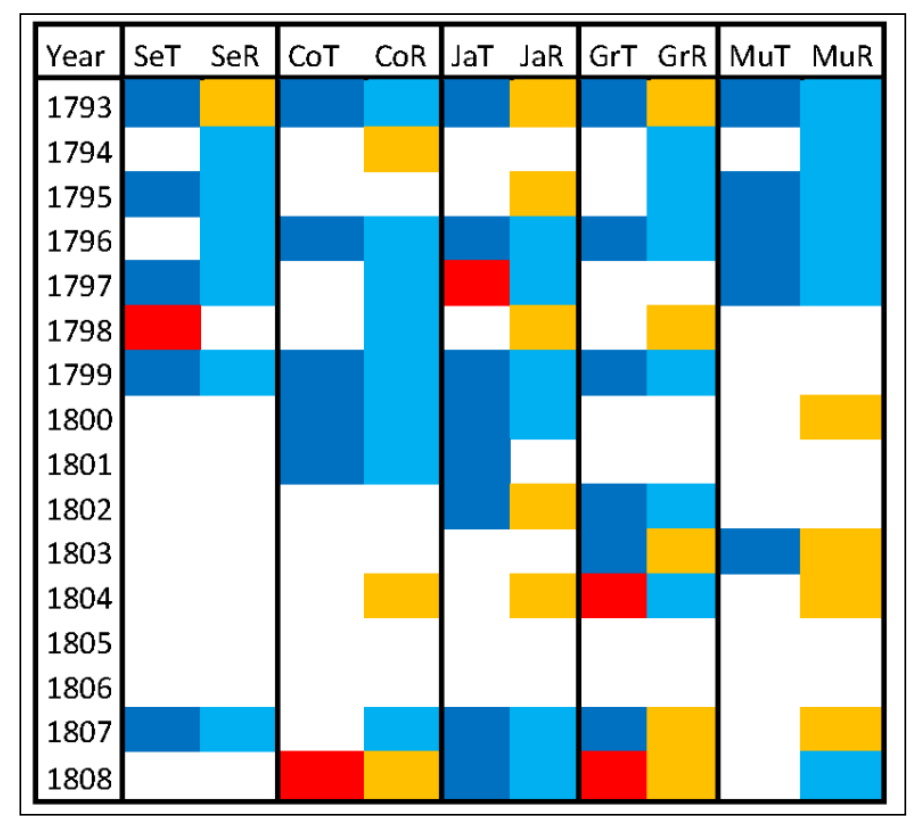

Figure 6. Spring mean conditions in southern provinces from 1793 to 1808. Se $=$ Seville; $C o=$ Córdoba; Ja = Jaén; $G r=$ Granada; $M u=$ Murcia $. T=$ temperature; $R=$ rainfall; Red $=$ warm; Blue $=$ Cold $;$ Orange $=$ dry; Cyan $=$ wet; White $=$ missing data or insufficient number of records $(<9)$.

\subsection{Extreme phenomena}

Although the information obtained is insufficient to establish index values for a particular province or over a given time period (season and/or year), it can still be useful for describing special weather events, including the occurrence of extreme phenomena. Extreme phenomena are collated using reports of their impact on crops, or their exceptional character. For example, the two floodings of the Segura River in Murcia in September 1793 and October 1797 are described, respectively: "ha llovido bastante, han causado algun daño las aguas del rio, por haber crecido en demasía" (it has rained quite a lot, the waters of the river have caused some damage because they have risen too much, issue 27, page 209, 1793), and "han sido tan excesivas las aguas en la [provincia] de Murcia, que habiendo salido de madre el rio Segura, ha causado crecidos daños en su huerta y la de Orihuela (the waters in the [province] of Murcia have been so excessive that, having broken the banks of the Segura River, caused a great deal of damage to its huerta (area of market gardens) and that of Orihuela, issue 86, page 217, 1797). The cold spell in January 1802 is described indicating "copiosas nieves nada comunes en este país" (copious snows not common in this country) in Córdoba (issue 8, page 57, 1802), and "temporal cruel y nunca visto en el pais, pues en todo lo que va del mes no ha cesado de nevar y llover, y tiene apariencias de continuar" (cruel stormy weather never seen in the country, for the whole month it has not stopped snowing and raining, and it appears 
that this will continue) in Jaén (issue 10, page 73,1802 ). It is noteworthy that severe droughts are barely mentioned. The dry conditions, even with references to pro-pluvia rogations were followed by rains that improved the harvests, for example in Valencia in February 1793 (issue 14, page 105, 1793) and Murcia in April 1793 (issue 9, volume 2, page 61,1793 ). Currently, the preparation a catalogue of extreme events based on the information provided by the CMEI is underway.

\section{Discussion}

The best proof for the reliability of this data source is to check other evidence from different data sources (qualitative and/or quantitative) to see if they show similar characteristics. As a first approach, other data sources related to the southern provinces were investigated. These are collated in the EMOSSv2 database (Rodrigo, 2019, http:// hdl.handle.net/10835/6806). This is a set of qualitative and instrumental data prior to 1850 from Cádiz, Sevilla, Malaga, Granada and Murcia. These data sources are local whereas CMEI frequently provides spatially averaged information for each province. The comparison cannot be exhaustive as different data sources refer to different periods. However, there are some short periods that allow a comparative exercise to be carried out.

In the case of Sevilla province, it is possible to compare this new data with existing information for the cities of Cádiz and Sevilla: the data for Cádiz are from the years 1799 and 1800 (Aréjula, 1806, referred to in EMOSSv2 as Ca1799-1800), and from $30^{\text {th }}$ October 1802 to $29^{\text {th }}$ December 1803 (Diario Comercial de Cádiz, Ca1802-1803 in EMOSSv2), while the Sevilla data were recorded in the Correo de Sevilla periodical (Se1803-1806 in EMOSSv2) from October 1803 to December 1806. The temporal resolution varies in these data sources (daily for Cádiz, daily and monthly for Sevilla); however, in general terms, there are clear similarities. For example, Ca1799-1800 indicates "grandes lluvias" (great rains) in Cádiz on $12^{\text {th }}$ January 1800 , coinciding with information on "lluvias excesivas" (excessive rains) in the CMEI report of $18^{\text {th }}$ January 1800 (issue 9, page 65, 1800); the weather in Cádiz from October to mid-December 1802 was rainy according to $\mathrm{Ca} 1802-1803$ and the reports from $30^{\text {th }}$ October to $11^{\text {th }}$ December of the same year in the CMEI indicate rainy conditions in the province of Sevilla (issues 92, page 279, to 104, page 825, 1802). From $15^{\text {th }}$ December 1802 onwards, Ca1802-1803 reports clear skies, while according to the CMEI (report dated $18^{\text {th }}$ December) "han cesado las lluvias y hace buen tiempo" (rains have ceased and there is good weather, issue 2, page 9, 1803). The Se1803-1806 source provides quantitative temperature information in years for which there are many corresponding gaps in the CMEI (1803-1806); nonetheless, it is sometimes possible to compare qualitative and quantitative data. For example, the cold conditions of December 1806 reported in the CMEI $\left(13^{\text {th }}\right.$ December, issue 103, page $811,1806)$, coincide with the daily maximum and minimum temperatures recorded in Se1803-1806 (11.9 $\mathrm{C}$ and $5^{\circ} \mathrm{C}$ on $10^{\text {th }}$ and $11^{\text {th }}$ December, respectively).

In the case of Granada province, it is possible to compare the daily data for Granada from May 1796 to September 1797 published in the El Mensajero periodical (Gr17961797 in EMOSSv2) and the seasonal data corresponding to Malaga from the autumn of 
1802 to the autumn of 1804 (Mendoza, 1813, Ma1802-1804 in EMOSSv2). There are remarkable matches in the information about a "atmósfera serena" (serene atmosphere) given in the CMEI and "cielos claros" (clear skies) recorded in Gr1796-1797, as well as the news regarding "lluvias copiosas" (copious rains, CMEI, report published on $11^{\text {th }}$ December, 1796 , issue 102 , page 809,1796 ) and the occurrence of rains on $4^{\text {th }}, 5^{\text {th }}, 6^{\text {th }}$ and $11^{\text {th }}$ December of the same year (Gr1796-1797). The winter of 1803 was very rainy according to Ma1802-1804, corresponding with the news in the CMEI, which noted that "en Málaga ha llovido abundantemente" (in Malaga it has rained abundantly, report of $4^{\text {th }}$ January 1803 , issue 4 , page 28,1803 ).

A similar comparison can be made using CMEI data for Murcia province and data extracted from the Diario de Cartagena periodical (Car1807 in EMOSSv2). In the period from February to December 1807, the information corresponds repeatedly - "atmósfera serena" (serene atmosphere) reported in the CMEI and "cielos claros" (clear skies) recorded in Car1807 as well as for descriptions of the cloud conditions, such as "nublado" (cloudy) according to Car1807 on 19 (overcast) according to the CMEI (reported on $21^{\text {st }}$ November, issue 98, page 761, 1807).

It is best to make a quantitative comparison of data from different sources. However, this can be a difficult task because the common periods for the different data sources are brief, and the time resolution is different - weekly for the CMEI, daily for the first instrumental meteorological series. However, we attempted to make this comparison by defining a monthly index for the CMEI data (It = monthly temperature index; Ir = monthly precipitation index). This index was obtained as the monthly average for the it and ir indexes assigned to each individual record. This monthly index was calculated only when the number of monthly records was satisfactory according to our criteria $(\geq 3$ for each month) and considering that some weeks belong to two consecutive months. In the case of temperature, the it index was redefined from -2 (very cold) to +2 (very warm) to extend the range of possible values to compare with the instrumental data.

Figure 7a shows the comparison between the CMEI's monthly temperature index (It) and the average monthly midday temperatures in Granada (Gr1796-1797) from June 1796 to September 1797. Due to the lack of a sufficient number of records, the It index was not calculated for some of the months. However, the Pearson's correlation coefficient (significant to a 95\% confidence level) was 0.60. A similar comparison was made with data for Sevilla from January 1799 to August 1800 (Fig. 7b). Here, the comparison was made between the CMEI It index for Sevilla Province and the average monthly temperature at noon according to Ca1799-1800. The result is a correlation coefficient equal to 0.86 , significant to a $95 \%$ confidence level. Figure $7 \mathrm{c}$ shows the comparison between the CMEI's monthly rainfall index (Ir) and the number of rainy days per month in Cádiz during the same period, according to Ca1799-1800. The number of rainy days has a strong correlation with the total amount of rain and is therefore a good approximation for estimating precipitation for the historical period. In this case, a correlation coefficient equal to 0.64 was obtained, significant to a $95 \%$ confidence level. Any possible discrepancies might be due to the character of the spatial average for all of the provinces recorded in the CMEI and the local nature of the instrumental data 
extracted from the EMOSSv2 data sources. Nevertheless, these good results allow us to have sufficient confidence in the reliability of the data extracted from the CMEI, and therefore trust that this reliability can be extended to other provinces such as Córdoba and Jaén, for which we do not have contemporary instrumental series.
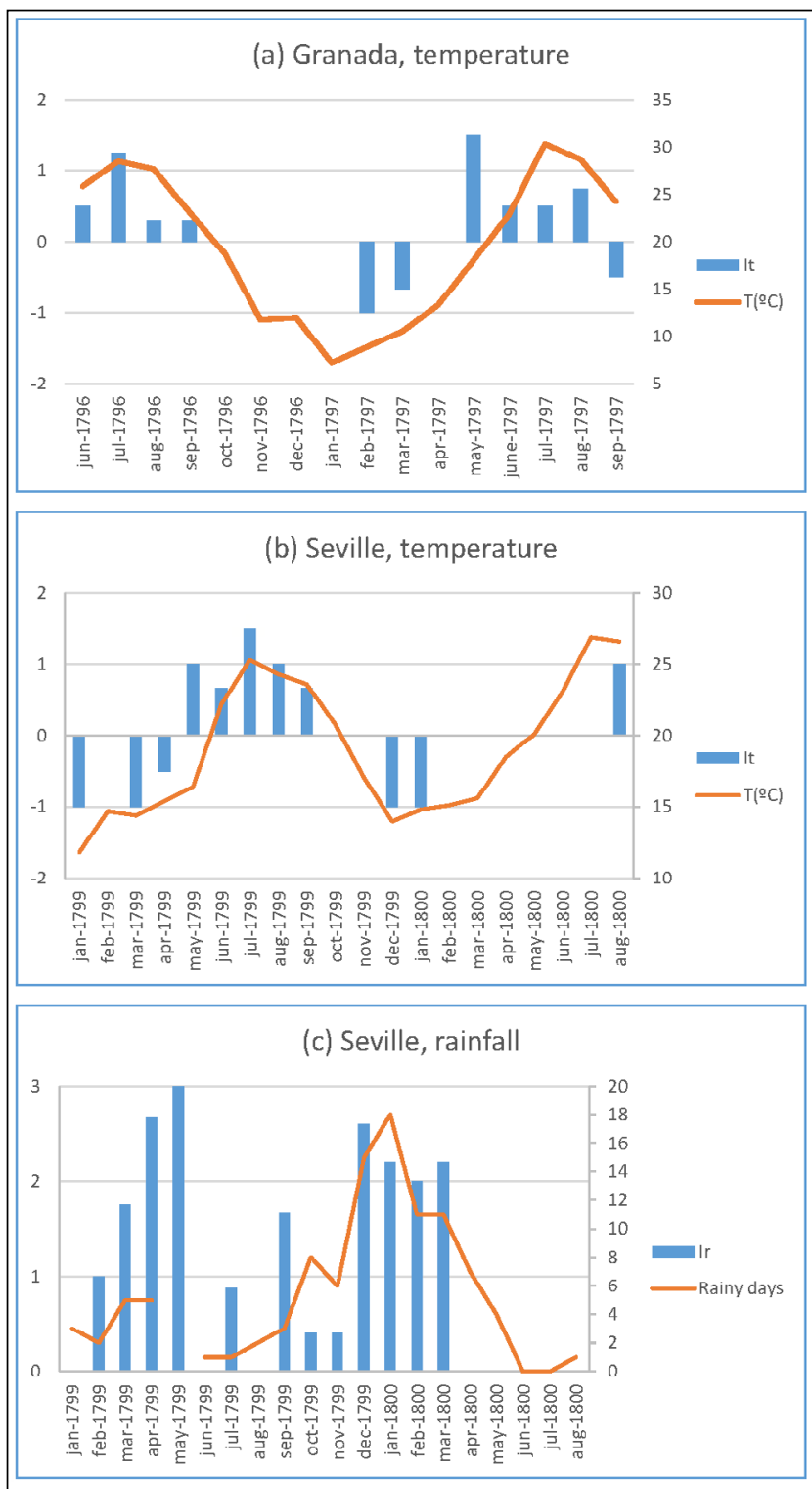

Figure 7. Monthly indices from CMEI and early meteorological data (EMOSSv2) in (a) Granada, temperature from June 1796 to September 1797; (b) Seville, temperature from January 1799 to August 1800; (c) Seville, rainy days from January 1799 to August 1800. 
This comparison also allows us to calibrate the indexes based on qualitative information, at least for those provinces with both types of data - qualitative for the CMEI, quantitative for the first instrumental series. Therefore, from the linear regression between the It and Ir indexes and the instrumental data, it is possible to perform a quantitative reconstruction of the meteorological variables during the period of study. We have postponed such analysis for future studies to avoid over-expanding this work.

\section{Conclusions}

The main objective of this work is to present a new data source (Correo Mercantil de España y sus Indias, abbreviated to CMEI) with qualitative climate information for Spain from 1792-1808. This short period is interesting as it is included the Minimum Dalton solar activity period; thus, this data can shed light on climate fluctuations for the Iberian Peninsula during a period of natural climate change. The information collected in the CMEI provides an overview of the spatial distribution of weather events on a weekly time scale. In addition, it provides information on areas for which there has been no data collected to date. Previous analyses show the reliability of this data source by contrasting the information it provides with data obtained from other independent data sources for the same period. The preliminary analysis focusing on the southern provinces of Spain shows the potential of this data source, and its usefulness for subsequent research. Future research should focus on the following objectives:

- Expanding the study to the full list of Spanish provinces detailed in the CMEI, which covers a large part of the Iberian Peninsula.

- Compiling weekly weather event maps for the entire recorded period.

- Preparing a catalogue of extreme phenomena for this period to obtain an overview of their intensity and spatial extension.

- Refining the indexing of the qualitative records based on vague and imprecise terms, using contemporary instrumental data.

- Calibrating and validating these indexes to obtain a quantitative reconstruction of weather conditions for the period of study.

\section{References}

Anduaga Egaña, A. 2012. Meteorología, ideología y sociedad en la España comtemporánea. Consejo Superior de Investigaciones Científicas, Madrid, $450 \mathrm{pp}$.

Anés Álvarez, G. 1981. Economía e ilustración en la España del siglo XVIII. Editorial Ariel, Barcelona, $215 \mathrm{pp}$.

Aréjula, J.M. 1806. Breve descripción de la fiebre amarilla padecida en Cádiz. Biblioteca de Andalucía, sgn: ANT-XIX-614 (http://www.bibliotecavirtualdeandalucia.es)

Barriendos, M. 1997. Climatic variations in the Iberian Peninsula during the late Maunder Minimum (AD 1675-1715): an analysis of data from rogation ceremonies. The Holocene 7 , 105-111. https://doi.org/10.1177/095968369700700110. 
Barriendos, M., Martín-Vide, J.,Peña, J.C., Rodríguez, R. 2002. Daily meteorological observations in Cádiz-San Fernando. Analysis of the documentary sources and the instrumental data content (1786-1996). Climatic Change 53, 151-170. https://doi.org/10.1007/978-94-010.0371-1_6.

Brázdil, R., Dobrovolný, P., Luterbacher, J., Moberg, A., Pfister, C., Wheeler, D., Zorita, E. 2010. European climate of the past 500 years: new challenges for historical climatology. Climatic Change 101, 7-40. https://doi.org/10.1007/s10584-009-9783-z.

CAN. 1792-1809. Correspondencia entre el Real Consulado de Santander y los señores Diego María Gallard y Eugenio Larruga, Archivo Histórico-Provincial de Cantabria, sgn: Real Consulado, Caja 65, Legajo 202.

Correo Literario y Económico de Sevilla. 1803-1806. Biblioteca de la Universidad de Sevilla, sgn: A059/042-051 (http://fondosdigitales.us.es)

Correo Mercantil de España y sus Indias. 1792-1808. Biblioteca Nacional, sgn: R/35350, AHS/11098 (hhtp://hemerotecadigital.bne)

Diario de Cartagena. 1807. Archivo Municipal de Murcia, sgn: 1-G-13/14, (http://archivodemurcia. es).

Diario Mercantil de Cádiz. 1802-1803. Cádiz Library, sgn: FL-PP-Est59. (http:www. bibliotecavirtualdeandalucia.es)

Domínguez-Castro, F., García-Herrera, R., Ribera, P., Barriendos, M. 2010. A shift in the spatial pattern of Iberian droughts during the $17^{\text {th }}$ century, Climate of the Past 6, 553-563. https:// doi.org/10.5194/cp-6-553-2010.

Domínguez-Castro, F., Vaquero, J.M., Rodrigo, F.S., Farrona, M.M., Gallego. M.C., GarcíaHerrera. R., Barriendos. M., Sánchez-Lorenzo, A. 2014 Early Spanish meteorological records (1780-1850), International Journal of Climatology 34, 593-603. https://doi.org/10.1002/ joc.3709.

Fernández-Fernández, M.I., Gallego, M.C., Domínguez-Castro, F., Trigo, R.M., García, J.A., Vaquero, J.M., Moreno Gozález, J.M., Castillo Durán, J. 2014. The climate of Zafra from 1750 to 1840: history and description of weather observations. Climatic Change 126, 107118. https://doi.org/10.1007/s10584-014-1201-5.

Fernández-Fernández, M.I., Gallego, M.C., Domínguez-Castro, F., Trigo, R.M., Vaquero, J.M. 2015. The climate in Zafra from 1750 to 1840: precipitation. Climatic Change 129, 267-280. https://doi.org/10.1007/s10584-014-1315-9.

García Fernández, J. 1959. El Correo Mercantil de España y sus Indias como fuente para el estudio de la Geografía. Estudios Geográficos 20, 143-145.

Giorgi, F. 2006. Climate change hot-spots. Geophysical Research Letters 33: 11217-11222. https:// doi.org/10.1029/2006GL025734.

Gómez-Mendoza, J., García-Álvarez, J. 2001. Organización política y administrativa. In: A. Gil Olcina, J. Gómez-Mendoza (Eds), Geografía de España, Editorial Ariel, Barcelona, pp. 575-594.

Jones, P.D., Briffa, K.R., Osborn, T.J.,Lough, J.M., Van Ommen, T.M., Vinther, B.M., Luterbacher, J., Wahl, E.R., Zwiers, F.W., Mann, M.E., Schmidt, G.A., Ammann, C.M., Buckley, B.M., Cobb, K.M., Esper, J., Goosse, H., Graham, N., Jansen, E., Kiefer, T., Kull, C., Küttel, M., Mosley-Thompson, E., Overpeck, J.T.N., Riedwy, N., Schulz, M., Tudhope, A.W., Villalba, R., Wanner, H., Wolff, E., Xoplaki, E. 2009. High-resolution palaeoclimatology of the last millennium: a review of current status and future prospects. The Holocene 19, 3-49, https:// doi.org/10.1177/0959683608098952.

Martín-Vide, J., Olcina Cantos, J. 2001. Climas y tiempos de España, Alianza Editorial, Madrid, $258 \mathrm{pp}$.

Mendoza, J. 1813. Historia de las epidemias padecidas en Málaga en los años de 1803 y 1804. Biblioteca Cánovas del Castillo (Málaga), sgn: Bueno-FAN-XIX-159 (http:// bibliotecavirtualdeandalucia.es). 
Mensagero económico y erudito de Granada 1796-1797. Biblioteca Universidad de Granada, sgn: FLA F-9-9-3 (http://www.bibliotecavirtualdeandalucia.es).

Písek, J., Brázdil, R. 2006. Responses of large volcanic eruptions in the instrumental and documentary climatic data over Central Europe. International Journal of Climatology 26, 439-459. https://doi.org/10.1002/joc.1249.

Rodrigo, F.S. 2019. Early meteorological data in southern Spain during the Dalton Minimum. International Journal of Climatology. https://doi.org/10.1002/joc.6041.

Semanario de Agricultura y Artes dirigido a los párrocos. 1797-1808. Biblioteca de la Universidad de Granada, sgn: B-81-31 a B-81-52.

UPV. 1793. Carta de Don Eugenio Larruga. Universitat Politécnica de Valencia, sgn: Caja 23, Legajo 111, signatura 3 (http://riunet.upv.es/handle/10251/19263).

Usokin, I.G. 2017. A history of solar activity over millennia. Living Reviews in Solar Physics 14 (3). https://doi.org/101007/s41116-017-0006-9.

Wagner, S., Zorita, E. 2005. The influence of volcanic, solar, and CO2 forcing on the temperature in the Dalton Minimum (1790-1830): a model study, Climate Dynamics 25, 205-218. https:// doi.org/10.1007/s00382-005-0029-0. 